\title{
Predicting the Compressive Strength of Portland Cement Concretes with the Addition of Fluidized Bed Combustion Fly Ashes from Bituminous Coal and Lignite
}

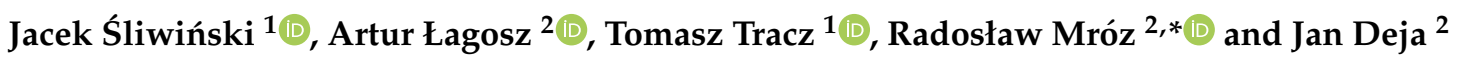 \\ 1 Faculty of Civil Engineering, Cracow University of Technology, 24 Warszawska St., 31-155 Cracow, Poland; \\ jacek.sliwinski@pk.edu.pl (J.Ś.); tomasz.tracz@pk.edu.pl (T.T.) \\ 2 Department of Building Materials Technology, Faculty of Material Science and Ceramics, AGH University of \\ Science and Technology, Al. Mickiewicza 30, 30-059 Kraków, Poland; alagosz@agh.edu.pl (A.Ł.); \\ deja@agh.edu.pl (J.D.) \\ * Correspondence: rmroz@agh.edu.pl; Tel.: +48-12-617-48-53
}

Citation: Śliwiński, J.; Łagosz, A.; Tracz, T.; Mróz, R.; Deja, J. Predicting the Compressive Strength of Portland Cement Concretes with the Addition of Fluidized Bed Combustion Fly Ashes from Bituminous Coal and Lignite. Minerals 2021, 11, 753. https://doi.org/10.3390/min11070753

Academic Editor: Keiko Sasaki

Received: 13 May 2021

Accepted: 7 July 2021

Published: 12 July 2021

Publisher's Note: MDPI stays neutral with regard to jurisdictional claims in published maps and institutional affiliations.

Copyright: (c) 2021 by the authors. Licensee MDPI, Basel, Switzerland. This article is an open access article distributed under the terms and conditions of the Creative Commons Attribution (CC BY) license (https:// creativecommons.org/licenses/by/ $4.0 /)$.

\begin{abstract}
This paper presents the results of an extensive experimental study on the effect of the addition of two types of fly ash produced during fluidized bed combustion of bituminous coal and lignite, which differ substantially in their chemical and mineral compositions, on the compressive strength of concrete. Concretes with water/binder ratios of $0.65,0.55$ and 0.45 made with CEM I $42.5 \mathrm{R}$ Portland cement and gravel aggregate were tested. The analyzed amounts of fly ash added to the binder were $0,15 \%$ and $30 \%$ by weight. Based on the results of compressive strength testing after 28 and 90 days of curing, the relationships with the water/binder ratio and fly ash content in the binder were determined. The fly ashes used were highly active and capable of pozzolanic reaction. The relationships established allow the compressive strength of concretes based on composite cementfly ash binder to be predicted with sufficient accuracy. The results presented in this study are an important contribution to the knowledge of concretes with combined binders. They have the exploratory value of establishing the dependence of compressive strength at 28 and 90 days on binder composition and water-binder ratio. In addition, they could be used almost directly in practical applications.
\end{abstract}

Keywords: cement; concrete; fluidized bed combustion fly ash; compressive strength; strength prediction

\section{Introduction}

Concrete production is associated with relatively high greenhouse gas (primarily carbon dioxide) emissions, mainly due to the use of clinker-based Portland cement [1]. One effective way of reducing these emissions is to use, where possible, cements with as high a content of nonclinker materials as possible: these materials are of a pozzolanic, hydraulic or passive nature and are, in many cases, waste products of the power or metallurgical industries [2]. A similar reduction in the emissions related to concrete production can be achieved by partially replacing cements with mineral additives at the stage of concrete mix production. This approach is common in concrete production technology, and it is regulated by standards dictating the rules for the use of coal combustion remains (fly and bottom ashes), silica fume or granulated blast-furnace slag [3]. In addition to environmental benefits, this either yields measurable economic effects for concrete manufacturers or allows the desirable properties of hardened concretes to be achieved. It should be mentioned that the amount of ash available on the Polish market is a result of the dominant role of bituminous coal and lignite as an energy source in the Polish energy sector.

The increasingly widespread use of silica fly ash (FA) from coal combustion in concrete and cement production and the changes occurring in the power generation sector have 
resulted in the shortfall of traditional fly ash in recent years [4,5]. Planned and ongoing investments in renewable energy sources as well as plans to limit the extraction of solid fossil fuels will result in a significant fly ash deficit in the construction materials industry. Hence, for several years now, interest has been growing in seeking alternatives to traditional concrete mineral additives that could be used as substitutes for traditional fly ash. Fluidized bed combustion fly ashes (FBC FA) $[1,2,4,5]$ are considered to be such a material; they are currently predominantly deposited on heaps close to the power plants where they are produced as a result of bituminous coal or lignite combustion.

In traditional coal-fired power plants, feeding coals are generally burned at a high temperature $\left(\geq 1200^{\circ} \mathrm{C}\right)$, which results in the formation of sintered and sphere-like structures, and FAs are enriched with aluminosilicate minerals and amorphous aluminosilicates [6-12].

Owing to the low temperature prevailing in fluidized beds (around $850{ }^{\circ} \mathrm{C}$ ), the resulting fly ash is distinctly different from the fly ash produced in conventional furnaces $[13,14]$. This is because during fluidized bed combustion, the liquid phase, which largely determines the physical and chemical properties of traditional fly ashes (FA), does not occur. Fluidized bed combustion fly ashes are therefore very weakly sintered and consist mainly of irregular grains of dehydrated and dehydroxylated waste rock minerals, with an almost amorphous microstructure and with anhydrite and calcium oxide contents higher than in traditional fly ashes. Additionally, hematite $\left(\mathrm{Fe}_{2} \mathrm{O}_{3}\right)$, periclase $(\mathrm{MgO})$ and small amounts of unburned carbon and calcite $\left(\mathrm{CaCO}_{3}\right)$ are also present in fluidized bed combustion fly ashes. Trace amounts of magnetite $\left(\mathrm{Fe}_{3} \mathrm{O}_{4}\right)$ and larnite $\left(\beta-\mathrm{Ca}_{2} \mathrm{SiO}_{4}\right)$ may occur as well. Due to the low combustion temperature, no mullite or glassy phase is present, and the calcium oxide present is only weakly sintered and thus quick to react with water [7,8,15-19].

To date, many studies have been conducted concerning the use of fluidized bed combustion fly ashes as components of various types of construction materials; these studies have yielded promising results in many cases $[2,4,5]$. They demonstrate that this type of fly ash could be successfully used as a pozzolanic additive and at the same time as a setting time regulator for common cements [13]. Some characteristics of this type of binder can be modified by additional mechanical treatment or enrichment with bottom waste from fluidized bed combustors [4,5,14,20-22]. The degree to which cement clinker was replaced in the cases reported in the literature ranged from 10 to $30 \%$ by weight for fluidized bed combustion fly ashes alone up to $70 \%$ where cement clinker was replaced with bottom waste from fluidized bed combustors [22]. In the literature, much attention has been given to the potential use of FBC FA in materials used to stabilize and provide a base for road infrastructure [23]. There have also been successful attempts to produce zerocement binders, especially alkali-activated ones, so-called geopolymers, using fluidized bed combustion fly ashes [24-26]. The work on cement-free binders containing fluidized bed combustion fly ashes also involves the search for synthetic zeolite materials [27] and binders other than common cements: for example, magnesium-sulfate cements [28]. In addition to the above potential applications, attempts have also been made to use fluidized bed combustion fly ashes in the manufacture of autoclaved products, autoclaved aerated concrete and silicate products $[29,30]$ as well as nonautoclaved aerated concrete [31].

Fluidized bed combustion fly ashes have also been used in cementitious concretes $[2,32,33]$. Attempts to use these fly ashes in the production of low-strength cementitious concretes and concretes for nonstructural applications (e.g., vibro-pressed concrete products or rollercompacted concretes) have been fairly common [32,34]. Data are also available concerning attempts to use fluidized bed combustion fly ashes for underwater concretes, where cement replacement level can be as high as $50 \%[35,36]$.

Currently, this group of fly ashes does not meet the formal requirements stipulated in EN 197-1 [37] for the main components of cement or the criteria set for concrete additives in EN-206 and EN 450-1 [3,38]. This means that the scope for the practical application of fly ashes produced by fluidized bed combustion of bituminous coal and lignite is currently small and in many potentially promising areas, marginal. However, the expected significant exacerbation of the shortfall of conventional fly ashes may result in a rapid change in 
thinking about this group of mineral additives. It appears very likely that in the near future, fluidized bed combustion fly ashes will become acceptable components in the binder and concrete production industry, provided that the relevant quality requirements are met. At that point, any information that could make the application of fluidized bed combustion fly ashes in both cement and concrete production more efficient will become useful. As already mentioned, in terms of their composition and physical properties, fluidized bed combustion fly ashes have no equivalent in the mineral additives currently in use. Hence, mastering the use of such fly ashes of varying chemical and mineral compositions will be crucial to the proper application of these materials. This is an important issue since fly ash components exhibit both strong pozzolanic properties and significant hydraulic activity.

In the publications known to the authors on the properties of concretes with a combined binder composed of Portland cement and fluidized ash addition, attention is mainly focused on the standard compressive strength after 28 days [14,39]. Moreover, usually, the analyses of fluidized ash usability are limited to concrete with an established water-binder ratio $[21,32,36]$.

In the presented studies, a whole family of concretes with different water-binder ratios $(0.45,0.50$ and 0.65$)$ representing the dominant majority of manufactured concretes was analyzed. The presented results relate to the usefulness of ash from fluidized bed combustion of bituminous coal and lignite. In addition, the effect of the composition of these concretes on the compressive strength after 90 days of curing was also studied, which illustrates the potential of the blended binder to developing strength beyond 28 days.

\section{Purpose and Scope of the Study}

The purpose of the presented study was to determine how the type and amount of fly ash additives produced during fluidized bed combustion of bituminous coal and lignite affect the basic property of structural concretes, i.e., compressive strength. The impact of the addition of fluidized bed combustion fly ashes obtained by combusting bituminous coal and lignite (the energy carriers used in two power stations located in southwestern Poland) was analyzed. Based on the results obtained, models have been proposed to estimate the compressive strength of concretes as a function of the varying water/binder ratio and fly ash content in the binder.

Three groups of structural concretes with different compositions were the subject of the study. Apart from the type of fly ash (bituminous coal-based-FBC FA (A) and lignite-based-FBC FA (B)) and its content in the binder ( $0,15 \%$ and $30 \%$ by weight), the water/binder ratio $(0.45,0.55$ and 0.65$)$ was another variable parameter in the composition of the concretes analyzed.

A total of 15 concretes were tested whose detailed formulations are given later in the paper. The testing of concrete mixes included the testing of consistency evaluated by the concrete slump test according to EN 12350-2 [39] and of air content determined by the pressure method according to EN 12350-7 [40]. Compressive strength was determined according to EN 12390-3 [41] on $150 \mathrm{~mm}$ cube specimens. The hardened concretes were characterized in terms of their compressive strength after 28 and 90 days of curing.

\section{Characteristics of Fluidized Bed Combustion Fly Ashes Used in the Study}

The fluidized bed combustion fly ashes collected for testing were subject to chemical composition assessment according to the procedures set forth in the EN 196-2 standard [42]. Based on the results of chemical composition tests, additional determinations of free calcium oxide according to EN 451-1 [43], X-ray diffraction analysis and thermal (DTA/TG/DTG) analyses, their quantitative mineral compositions were determined. The proportion of noncrystalline phases, which are residues from the thermal decomposition of clay minerals (kaolinite and illite group minerals), was determined by subtracting from $100 \%$ the determined amounts of crystalline components and unburned carbon. In order to characterize the basic physical properties of fluidized bed combustion fly ashes, their specific surface area was determined using the BET method (temperature $105^{\circ} \mathrm{C}$, degassing 
time: $16 \mathrm{~h}$ ), and the amount of water required for obtaining a paste with normal consistency was determined according to the procedure outlined in EN 196-3 [44].

The results of tests concerning the chemical composition and mineral composition of fluidized bed combustion fly ashes, their specific surface area as measured by the BET method and water demand are presented in Table 1. The fly ashes used in the study exhibited differences in their chemical and mineral compositions, including different proportions of amorphous phases. The chemical composition of fluidized bed combustion fly ashes from lignite combustion (FBC FA (B)) corresponded to calcareous fly ash (type W according to EN 197-1 [37]), whereas fluidized bed combustion fly ashes from bituminous coal combustion (FBC FA (A)) corresponded to siliceous fly ash (type V). Both types of fly ashes exhibited comparable $\mathrm{SO}_{3}$ contents, which were much higher than for conventional fly ashes. The predominant proportion of amorphous phases in both types of fluidized bed combustion fly ashes results in a high specific surface area and in a water demand more than twice as high as that of those fly ashes obtained through conventional bituminous coal and lignite combustion that are currently used as concrete or cement additives.

Table 1. Chemical and mineral composition of fluidized bed combustion fly ashes used in the study and their basic physical properties.

Percentage by Mass of the Component Concerned [\%]

Chemical Composition

\begin{tabular}{|c|c|c|}
\hline Loss on ignition, $1000^{\circ} \mathrm{C} / 1 \mathrm{~h}$ & 2.73 & 3.40 \\
\hline $\mathrm{SiO}_{2}$ & 36.47 & 47.18 \\
\hline $\mathrm{Fe}_{2} \mathrm{O}_{3}$ & 4.40 & 6.80 \\
\hline $\mathrm{Al}_{2} \mathrm{O}_{3}$ & 28.40 & 25.62 \\
\hline $\mathrm{TiO}_{2}$ & 3.84 & 1.08 \\
\hline $\mathrm{CaO}$ & 15.95 & 5.84 \\
\hline $\mathrm{MgO}$ & 1.65 & 0.15 \\
\hline $\mathrm{SO}_{3}$ & 3.80 & 3.62 \\
\hline $\mathrm{Na}_{2} \mathrm{O}$ & 1.64 & 1.18 \\
\hline $\mathrm{K}_{2} \mathrm{O}$ & 0.62 & 2.36 \\
\hline $\mathrm{Cl}^{-}$ & 0.03 & 0.10 \\
\hline Total: & 99.53 & 97.33 \\
\hline \multicolumn{3}{|c|}{ Mineral Composition: } \\
\hline $\mathrm{SiO}_{2}$ & 1.5 & 15.0 \\
\hline $\mathrm{CaSO}_{4}$ & 6.5 & 6.2 \\
\hline $\mathrm{CaO}$ & 4.7 & 0.3 \\
\hline $\mathrm{CaCO}_{3}$ & 4.5 & 1.6 \\
\hline Carbon & 0.1 & 1.7 \\
\hline $\begin{array}{l}\text { Amorphous phases resulting from the } \\
\text { thermal decomposition of clay minerals }\end{array}$ & 82.7 & 75.2 \\
\hline \multicolumn{3}{|c|}{ Physical Properties } \\
\hline Specific surface area according to BET $\left[\mathrm{m}^{2} / \mathrm{g}\right]$ & 12.1 & 13.5 \\
\hline $\begin{array}{l}\text { Water demand of the fly ash-water paste } \\
\text { [\% by weight }]\end{array}$ & 75 & 73 \\
\hline
\end{tabular}

Note: Analyses of the chemical composition of ashes were performed using the "wet" method, according to the procedures given in EN 196-2 [42], based on an averaged analytical sample taken from the batch of ashes received for testing. The procedure provides for two complete parallel determinations and presentation of average values, with the requirement of limited difference between determinations of individual elements. 


\section{Materials and Methods}

\subsection{Characteristics of Basic Concrete Mix Components}

\subsubsection{Cement}

CEM I 42.5R Portland cement with the characteristics shown in Tables 2 and 3 (manufacturer's data) was used as binder.

Table 2. Chemical and mineral composition of the cement used.

\begin{tabular}{cc}
\hline Component & Content [\%] \\
\hline & Chemical Composition \\
\hline $\mathrm{SiO}_{2}$ & 20.9 \\
$\mathrm{Al}_{2} \mathrm{O}_{3}$ & 5.8 \\
$\mathrm{Fe}_{2} \mathrm{O}_{3}$ & 3.2 \\
$\mathrm{CaO}$ & 65.4 \\
$\mathrm{MgO}$ & 1.4 \\
$\mathrm{SO}_{3}$ & 2.74 \\
$\mathrm{Na}_{2} \mathrm{O}_{\text {eq }}$ & 0.94 \\
$\mathrm{Cl}^{-}$ & 0.035 \\
& Mineral Composition of Clinker \\
\hline $\mathrm{C}_{3} \mathrm{~S}$ & \\
$\mathrm{C}_{2} \mathrm{~S}$ & 51.8 \\
$\mathrm{C}_{3} \mathrm{~A}$ & 20.9 \\
$\mathrm{C}_{4} \mathrm{AF}$ & 9.9 \\
\hline
\end{tabular}

Table 3. Properties of the cement used.

\begin{tabular}{cc}
\hline Property & Value \\
\hline Water demand [\% by weight] & 27.5 \\
Initial setting time [min] & 200 \\
Final setting time [min] & 255 \\
Specific surface area according to Blaine $\left[\mathrm{m}^{2} / \mathrm{kg}\right]$ & 304 \\
Compressive strength [MPa]: & \\
after 2 days & 28.6 \\
after 28 days & 54.6 \\
\hline
\end{tabular}

\subsubsection{Aggregate}

The aggregate consisted of good quality river aggregates: $0 / 2 \mathrm{~mm}$ river sand and gravel of the $2 / 8$ and $8 / 16 \mathrm{~mm}$ fractions. The characteristics of aggregate components are given in Table 4 . Their quantitative proportions were selected in order to minimize the void content. As a result, it was determined that the aggregate should consist of $0 / 2 \mathrm{~mm}$ sand at $32 \%$ by weight, $2 / 8 \mathrm{~mm}$ gravel at $38 \%$ by weight and $8 / 16 \mathrm{~mm}$ gravel at $30 \%$ by weight. The void content of aggregate with this grain size distribution was $24.8 \%$ by volume.

Table 4. Sand and gravel characteristics.

\begin{tabular}{cccc}
\hline Property & Sand 0/2 $\mathbf{~ m m}$ & Gravel 2/8 $\mathbf{~ m m}$ & Gravel 8/16 mm \\
\hline Fines content category according to EN & $\mathrm{f}_{3}$ & $\mathrm{f}_{1.5}$ & $\mathrm{f}_{1.5}$ \\
12620 [45] [\% by weight] & none & none & none \\
Organic pollutant content & 2.65 & 2.60 & 2.60 \\
Density [t/ $\mathbf{m}^{3}$ ] & 1.15 & 1.97 & 1.97 \\
Water absorption (WA24) according to & non-reactive & non-reactive & non-reactive \\
EN 12620 [45] [\% by weight] & - & $\mathrm{F}_{1}$ & $\mathrm{~F}_{1}$ \\
Alkaline reactivity & & & \\
Freeze-thaw resistance category & & \\
according to EN 12620 [45] &
\end{tabular}




\subsubsection{Admixtures}

It was assumed that the concrete mixes should exhibit a slump test result (according to EN 12350-2 [39]) of approximately $100 \mathrm{~mm}$, and their consistency should be stable for a minimum of $45 \mathrm{~min}$. To ensure that these requirements were met, a decision was made to use a plasticizer based on magnesium lignosulfonates and/or a superplasticizer based on modified polycarboxylate ethers.

\subsection{General Rules for Designing the Composition of the Concretes Analyzed}

The composition of reference concretes, except admixture content, was largely determined by the cement content values adopted. The applied cement quantities $(280,320$ and $360 \mathrm{~kg} / \mathrm{m}^{3}$ ) are typical for concretes with the water/cement ratios in question and, on the other hand, meet the requirements for minimum binder contents for different exposure classes.

Based on the assumed cement (or binder) amount and $w / c($ or $w / b$ ) ratio, the amount of water $(w)$ in each concrete was calculated:

$$
\mathrm{w}=\mathrm{c} \cdot w / c \text { or } \mathrm{w}=\mathrm{b} \cdot w / \mathrm{b}
$$

where: $\mathrm{c}$ or $\mathrm{b}-$ cement or blended binder content $\left[\mathrm{t} / \mathrm{m}^{3}\right] ; w / c$ or $w / b$-water-cement or water-binder ratio [-].

The amount of aggregate was then calculated from the absolute volume equation; subsequently, the aggregate was further separated into sand and two gravel fractions according to the proportions given in Section 4.1.2:

$$
\mathrm{a}=\mathrm{V}_{\mathrm{a}} \cdot \rho_{\mathrm{a}}=\left(1-\mathrm{V}_{\mathrm{c}}-\mathrm{V}_{\mathrm{w}}\right) \cdot \rho_{\mathrm{a}}=\left(1-\mathrm{c} / \rho_{\mathrm{c}}-\mathrm{w}\right) \rho_{\mathrm{a}}
$$

where: $\mathrm{V}_{\mathrm{a}}, \mathrm{V}_{\mathrm{c}}, \mathrm{V}_{\mathrm{w}}$-volumetric proportions of aggregate, cement and water, respectively, in the mixture $\left[\mathrm{m}^{3} / \mathrm{m}^{3}\right] ; \rho_{a}, \rho_{c}$-weighted average densities of aggregate $\left(2.60 \mathrm{t} / \mathrm{m}^{3}\right)$ and of cement $\left(3.1 \mathrm{t} / \mathrm{m}^{3}\right)$, respectively.

The quantities of admixtures (see Section 4.1.3) necessary to obtain the desired consistency of the concrete mixes were determined and verified experimentally by means of producing trial batches. The rheological admixture (superplasticizers) amounts specified further in the paper ensured that mixes with the desired properties were obtained.

Irrespective of the characteristics of the FBC FA (A) or (B) fluidized bed combustion fly ashes tested, chemical analyses of other batches of fly ashes collected cyclically from the same installations over an extended period of time showed that the $\mathrm{SO}_{3}$ content was variable and higher than $6.0 \%$ in some cases. In the fly ashes used in the study, the $\mathrm{SO}_{3}$ content never exceeded $4.0 \%$. Since the $\mathrm{SO}_{3}$ content of the CEM I $42.5 \mathrm{R}$ cement used is $2.74 \%$ and the total $\mathrm{SO}_{3}$ content in the binder should not exceed $3.5 \%$, the theoretical maximum content of fluidized bed combustion fly ashes in the binder could exceed $70 \%$. However, where the proportion of $\mathrm{SO}_{3}$ in fly ashes increases, e.g., to $6.0 \%$, the share of fly ashes should be limited to just $23 \%$ where the same type of cement is used. Therefore, and in view of the results of preliminary laboratory tests, a maximum proportion of $30 \%$ fluidized bed combustion fly ashes in the binder was adopted. Given the $\mathrm{SO}_{3}$ content of cement, this level of cement replacement is possible when using fly ashes with a $\mathrm{SO}_{3}$ content of no more than $5.3 \%$.

In addition to $\mathrm{SO}_{3}$, the free $\mathrm{CaO}$ content in fluidized ashes is also important. Similar to $\mathrm{SO}_{3}$, the free $\mathrm{CaO}$ content should be continuously controlled. The increase in the content of free lime in fluidized ash should not exceed $5 \%$ of its mass due to the risk of losing concrete consistency, as well as an unexpected increase in its temperature as a result of the formation of calcium hydroxide.

As mentioned previously, the main focus of the study included concretes produced with a binder in which the fluidized bed combustion fly ash content was $15 \%$ and $30 \%$ by weight of cement. The other principles for designing concretes with mixed cementfly ash binder were identical to those for reference concretes. In order to determine the 
volumetric proportions of paste and mortar, the following component densities were assumed: cement $-\rho_{\mathrm{c}}=3.1 \mathrm{t} / \mathrm{m}^{3}$; fluidized bed combustion fly ashes- $\rho_{\mathrm{fa}}=2.68 \mathrm{t} / \mathrm{m}^{3}$ (FBC FA (A)) and $2.75 \mathrm{t} / \mathrm{m}^{3}$ (FBC FA (B)); sand- $\rho_{\mathrm{s}}=2.65 \mathrm{t} / \mathrm{m}^{3}$.

\subsection{Composition of the Concretes Analyzed}

Tables 5-7 below present the detailed compositions of the concretes analyzed.

Table 5. Composition of concretes with $w / b$ ratio $=0.65$ without and with fluidized bed combustion fly ashes.

\begin{tabular}{|c|c|c|c|c|c|}
\hline \multirow{2}{*}{ Component $\left[\mathrm{kg} / \mathrm{m}^{3}\right]$} & \multicolumn{5}{|c|}{ Concrete } \\
\hline & REF-0.65 & $0.65-15 \mathrm{~A}$ & $0.65-15 B$ & $0.65-30 \mathrm{~A}$ & $0.65-30 \mathrm{~B}$ \\
\hline CEM I 42.5 R cement & 280 & \multicolumn{2}{|c|}{238} & \multicolumn{2}{|c|}{196} \\
\hline \\
\hline from lignite $(\mathrm{B})$ & - & - & 42 & - & 84 \\
\hline water & \multicolumn{5}{|c|}{182} \\
\hline $0 / 2 \mathrm{~mm}$ sand & 604 & \multicolumn{2}{|c|}{602} & \multicolumn{2}{|c|}{599} \\
\hline 2/8 mm gravel & 717 & \multicolumn{2}{|c|}{715} & \multicolumn{2}{|c|}{711} \\
\hline $8 / 16$ mm gravel & 567 & \multicolumn{2}{|c|}{564} & \multicolumn{2}{|c|}{561} \\
\hline plasticizer & $\begin{array}{c}1.26(0.45 \% \text { of } \\
\text { cement weight })\end{array}$ & $\begin{array}{c}1.54(0.55 \% \text { of } \\
\text { binder weight })\end{array}$ & $\begin{array}{c}1.82(0.65 \% \text { of } \\
\text { binder weight })\end{array}$ & $\begin{array}{c}2.52(0.90 \% \text { of } \\
\text { binder weight })\end{array}$ & $\begin{array}{c}2.52(0.90 \% \text { of } \\
\text { binder weight })\end{array}$ \\
\hline superplasticizer & - & - & - & $\begin{array}{c}1.68(0.60 \% \text { of } \\
\text { binder weight })\end{array}$ & $\begin{array}{c}1.54(0.55 \% \text { of } \\
\text { binder weight })\end{array}$ \\
\hline cement paste content $\left[\mathrm{m}^{3} / \mathrm{m}^{3}\right]$ & 0.272 & \multicolumn{2}{|c|}{0.275} & \multicolumn{2}{|c|}{0.277} \\
\hline mortar content $\left[\mathrm{m}^{3} / \mathrm{m}^{3}\right]$ & 0.500 & \multicolumn{2}{|c|}{0.502} & \multicolumn{2}{|c|}{0.503} \\
\hline slump test $[\mathrm{mm}]$ & 90 & 90 & 95 & 115 & 90 \\
\hline air content $[\%]$ & 2.0 & 2.0 & 2.1 & 1.7 & 2.2 \\
\hline
\end{tabular}

Table 6. Composition of concretes with $w / b$ ratio $=0.55$ without and with fluidized bed combustion fly ashes.

\begin{tabular}{|c|c|c|c|c|c|}
\hline \multirow{2}{*}{ Component $\left[\mathrm{kg} / \mathrm{m}^{3}\right]$} & \multicolumn{5}{|c|}{ Concrete } \\
\hline & REF-0.55 & $0.55-15 A$ & $0.55-15 B$ & $0.55-30 \mathrm{~A}$ & $0.55-30 B$ \\
\hline CEM I 42.5 R cement & 320 & \multicolumn{2}{|c|}{272} & \multicolumn{2}{|c|}{224} \\
\hline $\begin{array}{l}\text { fluidized bed combustion fly ashes: } \\
\text { from bituminous coal (A) } \\
\text { from lignite (B) }\end{array}$ & - & $\begin{array}{l}48 \\
-\end{array}$ & - & $\begin{array}{l}96 \\
-\end{array}$ & $\overline{96}$ \\
\hline water & \multicolumn{5}{|c|}{176} \\
\hline $0 / 2 \mathrm{~mm}$ sand & 597 & \multicolumn{2}{|c|}{593} & \multicolumn{2}{|c|}{591} \\
\hline $2 / 8 \mathrm{~mm}$ gravel & 709 & \multicolumn{2}{|c|}{705} & \multicolumn{2}{|c|}{702} \\
\hline $8 / 16 \mathrm{~mm}$ gravel & 560 & \multicolumn{2}{|c|}{556} & \multicolumn{2}{|c|}{554} \\
\hline plasticizer & \multicolumn{5}{|c|}{$2.90(0.90 \%$ of cement weight $)$} \\
\hline superplasticizer & $\begin{array}{c}0.80(0.40 \% \text { of } \\
\text { cement weight })\end{array}$ & $\begin{array}{c}2.56(0.95 \% \text { of } \\
\text { binder weight })\end{array}$ & $\begin{array}{c}2.72(0.95 \% \text { of } \\
\text { binder weight })\end{array}$ & $\begin{array}{c}3.52(1.25 \% \text { of } \\
\text { binder weight })\end{array}$ & $\begin{array}{c}4.80(1.65 \% \text { of } \\
\text { binder weight })\end{array}$ \\
\hline cement paste content $\left[\mathrm{m}^{3} / \mathrm{m}^{3}\right]$ & 0.279 & \multicolumn{2}{|c|}{0.282} & \multicolumn{2}{|c|}{0.284} \\
\hline mortar content $\left[\mathrm{m}^{3} / \mathrm{m}^{3}\right]$ & 0.505 & \multicolumn{2}{|c|}{0.506} & \multicolumn{2}{|c|}{0.507} \\
\hline slump test $[\mathrm{mm}]$ & 90 & 110 & 90 & 90 & 95 \\
\hline air content $[\%]$ & 1.9 & 1.8 & 1.8 & 1.8 & 1.9 \\
\hline
\end{tabular}


Table 7. Composition of concretes with $w / b$ ratio $=0.45$ without and with fluidized bed combustion fly ashes.

\begin{tabular}{|c|c|c|c|c|c|}
\hline \multirow{2}{*}{ Component $\left[\mathrm{kg} / \mathrm{m}^{3}\right]$} & \multicolumn{5}{|c|}{ Concrete } \\
\hline & REF-0.45 & $0.45-15 \mathrm{~A}$ & $0.45-15 B$ & $0.45-30 \mathrm{~A}$ & $0.45-30 \mathrm{~B}$ \\
\hline CEM I 42.5 R cement & 360 & \multicolumn{2}{|c|}{306} & \multicolumn{2}{|c|}{252} \\
\hline $\begin{array}{l}\text { fluidized bed combustion fly ashes: } \\
\text { from coal (A) } \\
\text { from lignite (B) }\end{array}$ & - & 54 & $\overline{54}$ & $\begin{array}{l}108 \\
-\end{array}$ & $\overline{108}$ \\
\hline water & \multicolumn{5}{|c|}{162} \\
\hline $0 / 2 \mathrm{~mm}$ sand & 597 & \multicolumn{2}{|c|}{594} & \multicolumn{2}{|c|}{589} \\
\hline $2 / 8 \mathrm{~mm}$ gravel & 709 & \multicolumn{2}{|c|}{705} & \multicolumn{2}{|c|}{700} \\
\hline $8 / 16 \mathrm{~mm}$ gravel & 560 & \multicolumn{2}{|c|}{557} & \multicolumn{2}{|c|}{552} \\
\hline plasticizer & \multicolumn{5}{|c|}{$3.24(0.90 \%$ of cement weight $)$} \\
\hline superplasticizer & $\begin{array}{l}1.44(0.40 \% \text { of } \\
\text { cement weight) }\end{array}$ & $\begin{array}{l}3.42 \text { ( } 0.95 \% \text { of } \\
\text { binder weight })\end{array}$ & $\begin{array}{c}3.42 \text { ( } 0.95 \% \text { of } \\
\text { binder weight) }\end{array}$ & $\begin{array}{c}4.50 \text { (1.25\% of } \\
\text { binder weight) }\end{array}$ & $\begin{array}{r}5.94(1.65 \% \text { of } \\
\text { binder weight })\end{array}$ \\
\hline cement paste content $\left[\mathrm{m}^{3} / \mathrm{m}^{3}\right]$ & 0.278 & \multicolumn{2}{|c|}{0.281} & \multicolumn{2}{|c|}{0.284} \\
\hline mortar content $\left[\mathrm{m}^{3} / \mathrm{m}^{3}\right]$ & 0.503 & \multicolumn{2}{|c|}{0.505} & \multicolumn{2}{|c|}{0.506} \\
\hline slump test $[\mathrm{mm}]$ & 90 & 95 & 90 & 90 & 100 \\
\hline air content $[\%]$ & 1.9 & 1.7 & 1.5 & 1.8 & 1.7 \\
\hline
\end{tabular}

It should be noted that the fluidized bed combustion fly ashes used in the study significantly increase the amount of admixtures required to ensure the desired consistency and to maintain it for at least $45 \mathrm{~min}$. This effect is significantly different from the effect of conventional silica fly ashes on the rheological properties of concrete mixes. Furthermore, the composition summary shows that the amount of admixtures required is higher when using FBC FA (B) obtained by combusting lignite, which may be due to the higher content of free calcium oxide in its composition.

\subsection{Procedure for Producing Mixes and Specimens, Curing Conditions}

The components were mixed in a mixer with a nominal capacity of $0.150 \mathrm{~m}^{3}$. Each batch had a volume of approximately $0.100 \mathrm{~m}^{3}$. After the initial mixing of sand with gravel, cement or cement and fly ash were added over a period of $1 \mathrm{~min}$, and the mix was stirred for another minute. While stirring continued, water was added together with the planned amount of admixtures. The mix was further stirred for about $5 \mathrm{~min}$.

Cube specimens of $150 \mathrm{~mm}$ were formed in plastic molds suitable for pneumatic demolding. Subsequently, they were compacted on a vibrating table in accordance with the recommendations given in EN 12390-2 [46]. The specimens remained covered with plastic film for $48 \mathrm{~h}$ until demolding. After demolding, the specimens were placed over water in airtight containers equipped with an installation which ensured a constant temperature of $20{ }^{\circ} \mathrm{C} \pm 3{ }^{\circ} \mathrm{C}$, where they remained until day 28 or 90 of curing. Thus, the specimens were stored in accordance with EN 12390-2 [46]. Compressive strength testing was carried out after three more days of storing specimens in air with a relative humidity of approximately $50 \%$.

\section{Test Results}

\subsection{Properties of the Concrete Mix}

For all concretes analyzed (reference concretes and those containing different quantities of both types of fluidized bed combustion fly ashes), the assumed consistency (slump test according to EN-12350-2 [39]) was obtained. The time during which the consistency remained stable was, irrespective of fly ash content, at least $45 \mathrm{~min}$. The air content of the mixes was correct and met the $\leq 2.5 \%$ volume requirement in all cases. 


\subsection{Compressive Strength of Hardened Concretes}

Detailed results of compressive strength testing after 28 and 90 days for specimens made from the concretes analyzed are presented in Table 8.

Table 8. Results of compressive strength testing of concretes.

\begin{tabular}{|c|c|c|c|c|c|}
\hline \multirow{2}{*}{$w / c$ or $w / b$} & \multirow{2}{*}{ Concrete } & \multicolumn{4}{|c|}{ Compressive Strength after Curing [MPa]: } \\
\hline & & $\mathrm{f}_{\mathrm{ci} 28}$ & Mean $\mathbf{f}_{\mathrm{cm} 28}$ & $\mathrm{f}_{\mathrm{ci} 90}$ & Mean $\mathrm{f}_{\mathrm{cm} 90}$ \\
\hline \multirow{5}{*}{0.45} & REF-0.45 & $50.2 ; 53.8 ; 53.3 ; 52.9 ; 52.7 ; 51.1$ & 52.3 & $53.3 ; 58.2 ; 59.7 ; 60.6 ; 57.1 ; 57.1$ & 57.7 \\
\hline & $0.45-15 \mathrm{~A}$ & $53.6 ; 57.1 ; 54.051 .1 ; 52.2 ; 50.0$ & $53.2(102 \%$ ref $)$ & $52.2 ; 55.8 ; 55.5 ; 56.2 ; 57.0 ; 60.0$ & 56.1 (97\% ref) \\
\hline & $0.45-30 \mathrm{~A}$ & $54.9 ; 52.7 ; 55.1 ; 52.4 ; 50.9 ; 52.2$ & 53.5 (102\% ref) & $54.2 ; 56.2 ; 52.0 ; 58.0 ; 56.6 ; 57.1$ & 56.4 (98\% ref) \\
\hline & $0.45-15 B$ & $55.1 ; 54.9 ; 55.158 .7 ; 55.8 ; 57.1$ & 56.2 (107\% ref) & $61.8 ; 64.4 ; 64.0 ; 61.3 ; 64.9 ; 63.1$ & 62.1 (108\% ref) \\
\hline & $0.45-30 \mathrm{~B}$ & $54.4 ; 59.9 ; 60.457 .3 ; 54.7 ; 57.3$ & 57.9 (111\% ref) & $64.0 ; 64.4 ; 63.5 ; 64.0 ; 61.1 ; 62.9$ & $63.6(110 \%$ ref $)$ \\
\hline \multirow{5}{*}{0.55} & REF-0.55 & $53.3 ; 52.7 ; 46.247 .3 ; 46.2 ; 48.0$ & 49.5 & $60.2 ; 55.8 ; 54.9 ; 51.5 ; 54.7 ; 51.5$ & 55.3 \\
\hline & $0.55-15 \mathrm{~A}$ & $52.2 ; 52.7 ; 53.148 .9 ; 49.3 ; 50.0$ & 51.4 (104\% ref) & $58.4 ; 56.4 ; 56.4 ; 53.8 ; 49.8 ; 54.7$ & $55.6(100 \%$ ref $)$ \\
\hline & $0.55-30 \mathrm{~A}$ & $51.6 ; 51.1 ; 53.146 .7 ; 48.2 ; 47.3$ & 50.0 (101\% ref) & $57.5 ; 54.7 ; 52.2 ; 51.1 ; 54.4 ; 52.0$ & 53.5 (97\% ref) \\
\hline & $0.55-15 B$ & $52.0 ; 52.7 ; 51.847 .6 ; 43.1 ; 49.1$ & 50.6 (102\% ref) & $59.5 ; 58.4 ; 54.0 ; 56.2 ; 54.7 ; 54.2$ & $56.6(102 \%$ ref $)$ \\
\hline & $0.55-30 \mathrm{~B}$ & $54.2 ; 51.6 ; 55.849 .3 ; 52.0 ; 49.8$ & 52.1 (105\% ref) & $60.9 ; 62.0 ; 58.0 ; 55.1 ; 56.0 ; 57.8$ & 57.9 (105\% ref) \\
\hline \multirow{5}{*}{0.65} & REF-0.65 & $37.8 ; 38.7 ; 38.936 .9 ; 38.0 ; 40.9$ & 38.6 & $44.2 ; 48.9 ; 45.3 ; 46.2 ; 43.8 ; 47.1$ & 45.8 \\
\hline & $0.65-15 \mathrm{~A}$ & $34.2 ; 40.4 ; 35.837 .8 ; 41.1 ; 42.0$ & 38.0 (98\% ref) & $43.5 ; 44.0 ; 48.245 .3 ; 46.0 ; 44.9$ & 44.6 (97\% ref) \\
\hline & $0.65-30 \mathrm{~A}$ & $39.6 ; 39.1 ; 42.041 .3 ; 41.3 ; 42.9$ & 41.0 (106\% ref) & $45.1 ; 45.3 ; 43.545 .5 ; 44.7 ; 42.7$ & 44.9 (98\% ref) \\
\hline & $0.65-15 B$ & $41.6 ; 44.7 ; 42.441 .8 ; 43.3 ; 43.1$ & 42.7 (111\% ref) & $47.8 ; 49.1 ; 46.949 .3 ; 45.5 ; 45.7$ & 47.6 (104\% ref) \\
\hline & $0.65-30 \mathrm{~B}$ & $47.3 ; 43.6 ; 43.344 .9 ; 44.2 ; 42.9$ & $44.4(114 \%$ ref $)$ & $52.9 ; 47.5 ; 53.551 .8 ; 47.5 ; 44.0$ & $49.6(108 \%$ ref $)$ \\
\hline
\end{tabular}

Note: All individual compressive strength determinations were completed with satisfactory failure in accordance with the notations in EN 12390-3 [41].

In the case of concretes with the addition of fly ash (A), their compressive strengths after 28 days of curing were very similar to those of the reference concretes and represented from 98 to $106 \%$ of the reference strength. In concretes with lignite ash (B), their strengths were slightly higher than those of the reference concretes and were between 102 and 115\% of the reference strength. Similar relationships were found for the strengths after 90 days of curing. The strength of the concretes with ash addition represents 97 to $110 \%$ of the reference concrete strength. It should be noted that there was no significant effect of the water-binder " $w / b$ " ratio on the discussed relationships.

\section{Analysis of Results}

The results presented in Table 8 were approximated using a linear function and a second-degree polynomial. The analysis included 54 results from each of the $\mathrm{f}_{\mathrm{c} 28}$ and $\mathrm{f}_{\mathrm{c} 90}$ strength tests. The approximation was performed using the STATISTICA program. Approximation results are presented in Table 9. These two functions showed similarly high accuracy in describing the dependence of the compressive strength of concretes after 28 and 90 days of curing on the values of the water-binder ratio and the fluidized ash content. Table 9 includes regression equations, correlation coefficients and $\beta$ standardized correlation coefficients. For multiple regression analysis, the latter coefficient allows the significance of the predictors present in the model to be compared. The coefficient takes values from -1 to 1 , where values close to 0 indicate a very weak relationship between the predictor and the dependent variable. $\beta$ values above 0 indicate that an increase in the value of the predictor is accompanied by an increase in the value of the dependent variable, and it is vice versa for values below 0 . 
Table 9. Regression equations describing the $\mathrm{f}_{\mathrm{c} 28}$ or $\mathrm{f}_{\mathrm{c} 90}=\mathrm{f}(w / b ; \mathrm{aA} / \mathrm{b}$ or $\mathrm{aB} / \mathrm{b})$ relationships and their characteristics.

\begin{tabular}{|c|c|c|c|c|}
\hline \multirow{2}{*}{$\begin{array}{l}\text { Concrete with } \\
\text { Fly Ashes }\end{array}$} & \multirow{2}{*}{ Regression Equation } & \multirow{2}{*}{$\begin{array}{l}\text { Multiple Correlation } \\
\text { Coefficients R }\left(\mathbf{R}^{2}\right)\end{array}$} & \multicolumn{2}{|c|}{ Standardized $\beta$ Correlation Coefficients } \\
\hline & & & $w / b_{\text {beta }}$ & $a A / b_{\text {beta }}$ or $a B / b_{\text {beta }}$ \\
\hline \multirow{8}{*}{$\begin{array}{l}\text { A (from } \\
\text { bituminous } \\
\text { coal) }\end{array}$} & \multirow{2}{*}{$\mathrm{f}_{\mathrm{c} 28}=83.59-67.08(w / b)+4.35(\mathrm{aA} / \mathrm{b})$} & 0.891 & \multirow{4}{*}{-0.89 (significant) } & \multirow{4}{*}{+0.086 (insignificant) } \\
\hline & & $(0.794)$ & & \\
\hline & \multirow{2}{*}{$\begin{array}{c}\mathrm{f}_{\mathrm{c} 28}=-26.52+346.72(w / b)-8.55(\mathrm{aA} / \mathrm{b})- \\
380.28(w / b)^{2}+30.00(w / b)(\mathrm{aA} / \mathrm{b})-11.97(\mathrm{aA} / \mathrm{b})^{2}\end{array}$} & 0.940 & & \\
\hline & & $(0.884)$ & & \\
\hline & \multirow{2}{*}{$\mathrm{f}_{\mathrm{c} 90}=84.13-56.28(w / b)-4.17(\mathrm{aA} / \mathrm{b})$} & 0.810 & \multirow{4}{*}{-0.81 (significant) } & \multirow{4}{*}{-0.09 (insignificant) } \\
\hline & & $(0.657)$ & & \\
\hline & \multirow{2}{*}{$\begin{array}{c}\mathrm{f}_{\mathrm{c} 90}=-65.13+500.33(w / b)-9.59(\mathrm{aA} / \mathrm{b})- \\
507.22(w / b)^{2}+8.88(w / b)(\mathrm{aA} / \mathrm{b})+2.34(\mathrm{aA} / \mathrm{b})^{2}\end{array}$} & 0.894 & & \\
\hline & & $(0.790)$ & & \\
\hline \multirow{8}{*}{$\mathrm{B}$ (from lignite) } & \multirow{2}{*}{$\mathrm{f}_{\mathrm{c} 28}=83.50-66.78(w / b)+15.55(\mathrm{aB} / \mathrm{b})$} & 0.928 & \multirow{4}{*}{-0.88 (significant) } & \multirow{4}{*}{+0.306 (significant) } \\
\hline & & $(0.861)$ & & \\
\hline & \multirow{2}{*}{$\begin{array}{c}\mathrm{f}_{\mathrm{c} 28}=38.13+103.47(w / b)+14.58(\mathrm{aB} / \mathrm{b})- \\
156.67(w / b)^{2}+13.89(w / b)(\mathrm{aB} / \mathrm{b})-22.22(\mathrm{aB} / \mathrm{b})^{2}\end{array}$} & 0.942 & & \\
\hline & & $(0.887)$ & & \\
\hline & \multirow{2}{*}{$\mathrm{f}_{\mathrm{c} 90}=92.21-70.75(w / b)+13.05(\mathrm{aB} / \mathrm{b})$} & 0.929 & \multirow{4}{*}{-0.90 (significant) } & \multirow{4}{*}{ +0.248 (significant) } \\
\hline & & $(0.864)$ & & \\
\hline & \multirow{2}{*}{$\begin{array}{c}\mathrm{f}_{\mathrm{c} 90}=39.66+121.46(w / b)+28.84(\mathrm{aB} / \mathrm{b})- \\
172.50(\mathrm{w} / \mathrm{b})^{2}+16.39(w / b)(\mathrm{aB} / \mathrm{b})-22.59(\mathrm{aB} / \mathrm{b})^{2}\end{array}$} & 0.836 & & \\
\hline & & $(0.698)$ & & \\
\hline
\end{tabular}

As demonstrated, both the linear function and the second-degree polynomial describe the test results with similar degrees of accuracy. The conclusion may be drawn that for both the linear function and the second-degree polynomial, about $80 \%$ of the variation in compressive strength $\left(\mathrm{f}_{\mathrm{c} 28}\right.$ and $\left.\mathrm{f}_{\mathrm{c} 90}\right)$ can be explained by the $w / b$ and $\mathrm{aA} / \mathrm{b}$ or $\mathrm{aB} / \mathrm{b}$ predictors. Figures 1 and 2 show the proposed regression functions.

It should be stressed that the factor which has the most impact on the strength (both after 28 and after 90 days of curing) for both types of fluidized bed combustion fly ashes used is the water/binder $(w / b)$ ratio. In the case of concretes with bituminous coal fly ash A, fly ash content has virtually no effect on either the strength at 28 days or the strength at 90 days. This may therefore be interpreted to mean that within the dosage range adopted (up to $30 \%$ of the original cement weight), the FBC FA (A) addition almost fully replaces cement with respect to compressive strength properties. This means that the chemical activity and pozzolanic properties of these fly ashes are sufficiently high such that, according to EN 206 [3] (of course, only with respect to the compressive strength criterion), this type of fluidized bed combustion fly ashes could be assigned the $\mathrm{k}$ cementitious efficiency factor close to 1.0 as a concrete additive. This is confirmed by the calculations of $\mathrm{k}$-factor values (according to Atis [47]) conducted in Table 10 using Equation (3):

$$
k=\frac{c}{a}\left(\frac{f(t)_{c a}}{f(t)_{c c}}-1\right)+1
$$

where: $f(t)_{c c}, f(t)_{c a}$-compressive strength of (reference) concrete made exclusively with cement and of concrete made with cement-fly ash binder, respectively [MPa]; $c, a-$ cement and fly ash content in concrete $\left[\mathrm{kg} / \mathrm{m}^{3}\right]$, respectively. 


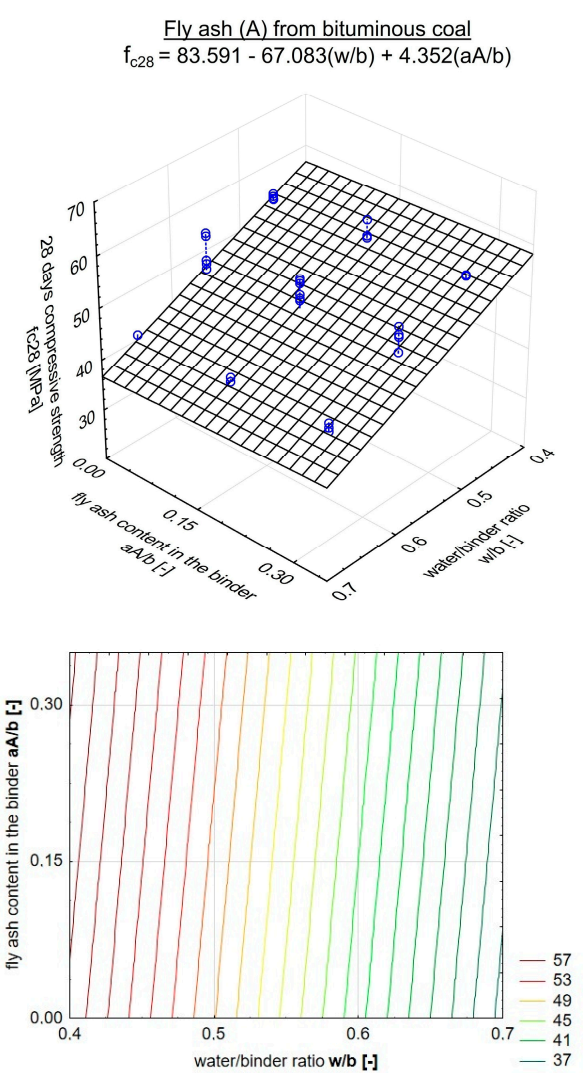

(a)

Fly ash (A) from bituminous coal $380.28(\mathrm{w} / \mathrm{b})^{2}+30.00(\mathrm{w} / \mathrm{b})(\mathrm{aA} / \mathrm{b})-11.97(\mathrm{aA} / \mathrm{b})^{2}$
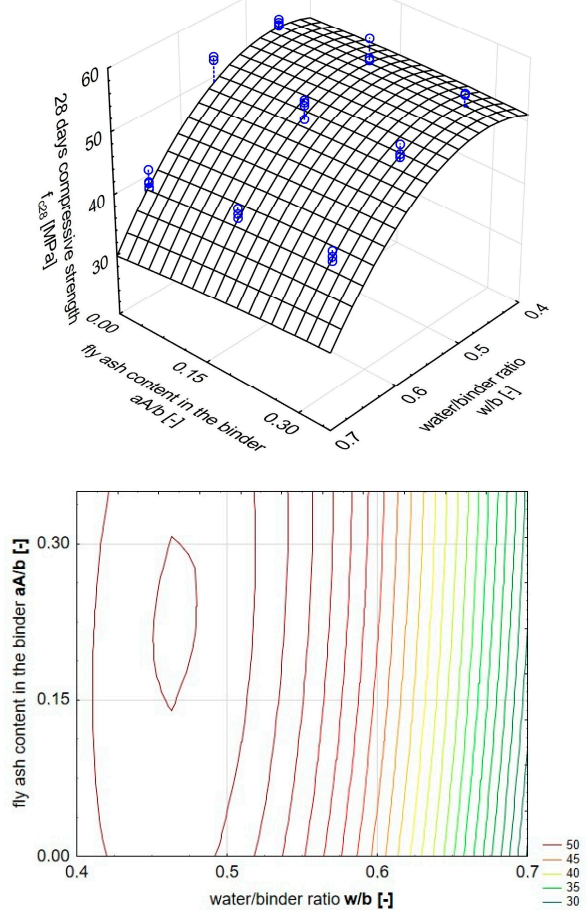

(c)

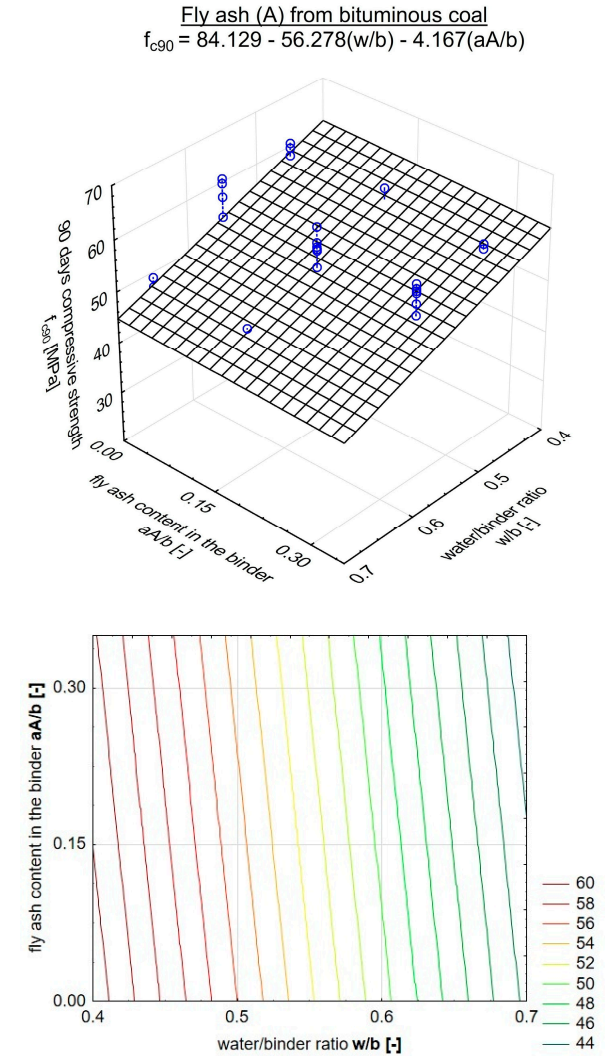

(b)
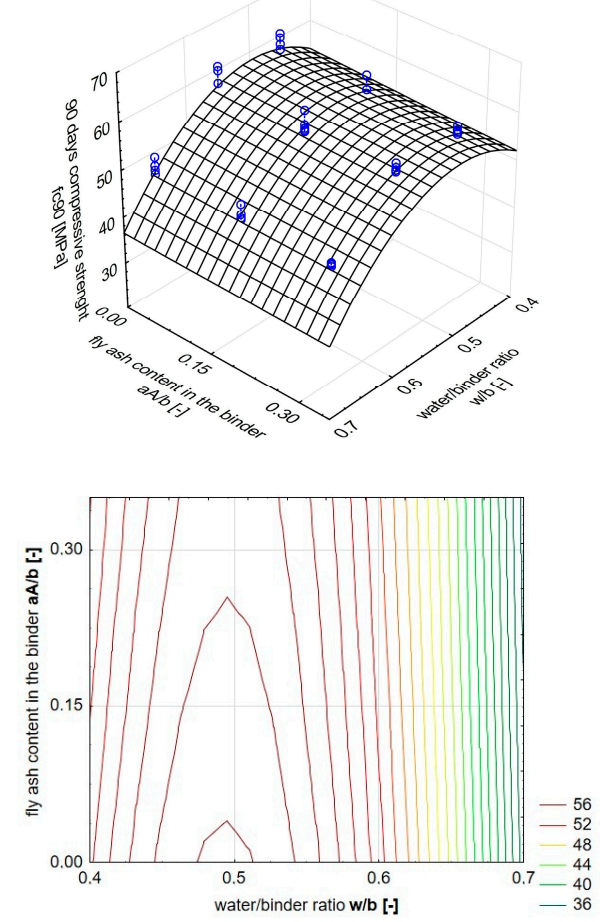

(d)

Figure 1. Compressive strength of concretes with fly ash addition A (bituminous coal) after 28 $(\mathbf{a}, \mathbf{c})$ and $90(\mathbf{b}, \mathbf{d})$ days; test results approximated using a linear function $(\mathbf{a}, \mathbf{b})$ and a second-degree polynomial $(\mathbf{c}, \mathbf{d})$. 
Fly ash (B) from lignite $f_{c 28}=83.500+66.778(w / b)+15.556(a B / b)$
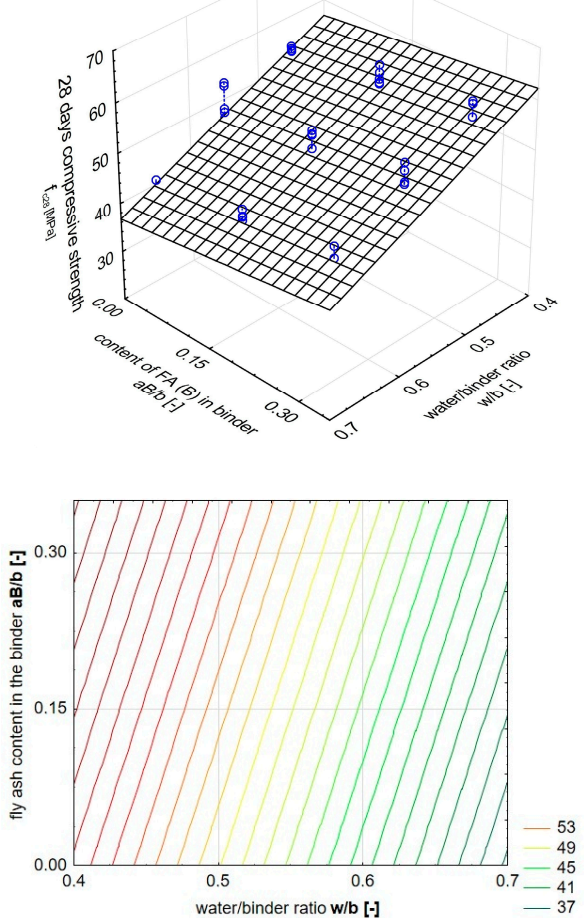

(a)

Fly ash (B) from lignite $f_{c 28}=38.13+103.47(w / b)+14.58(a B / b)-156.67(w / b)^{2}+$ $13.89(\mathrm{w} / \mathrm{b})(\mathrm{aB} / \mathrm{b})-22.22(\mathrm{aB} / \mathrm{b})^{2}$
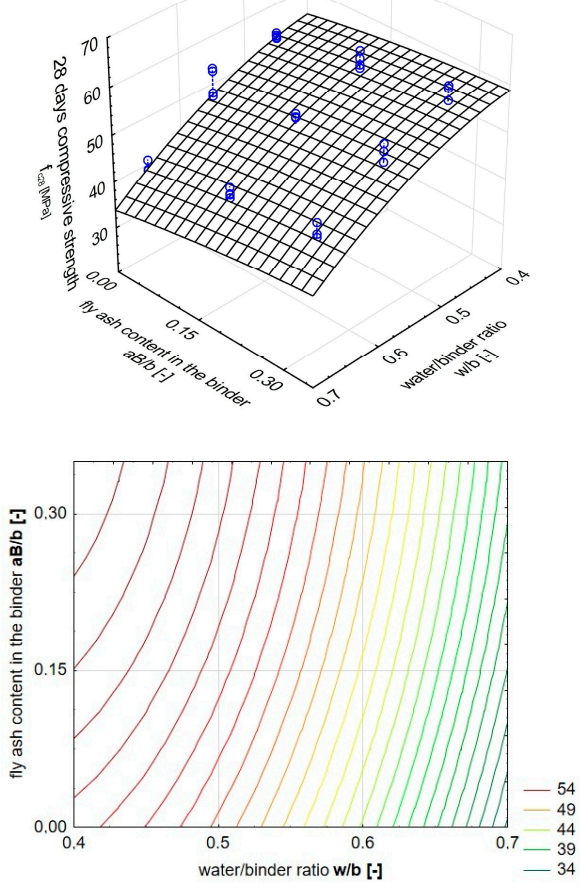

(c)
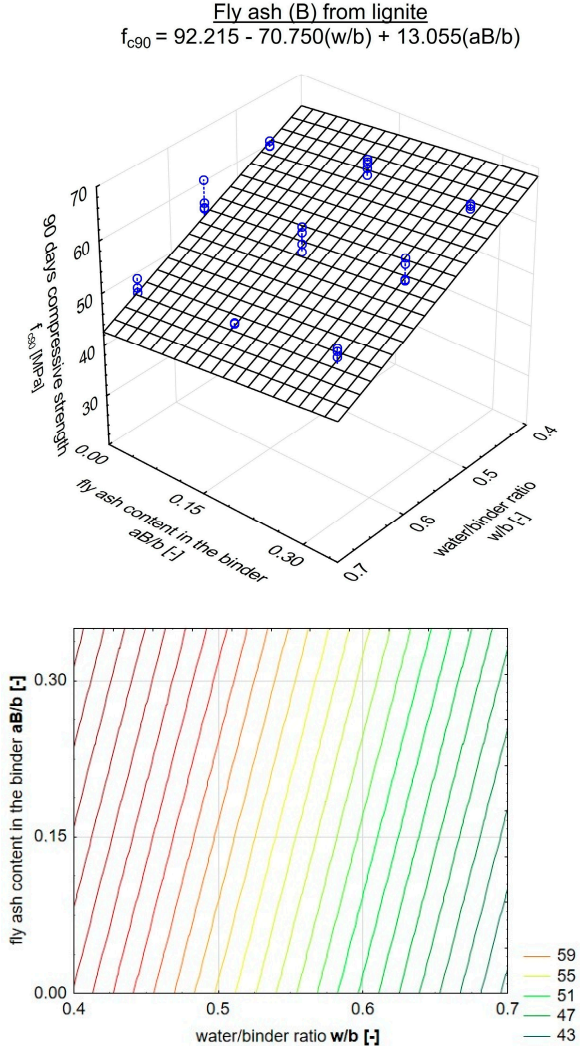

(b)

Fly ash (B) from lignite

$f_{c 90}=39.66+121.46(w / b)+28.84(a B / b)-172.50(w / b)^{2}+$ $16.39(\mathrm{w} / \mathrm{b})(\mathrm{aB} / \mathrm{b})-22.59(\mathrm{aB} / \mathrm{b})^{2}$
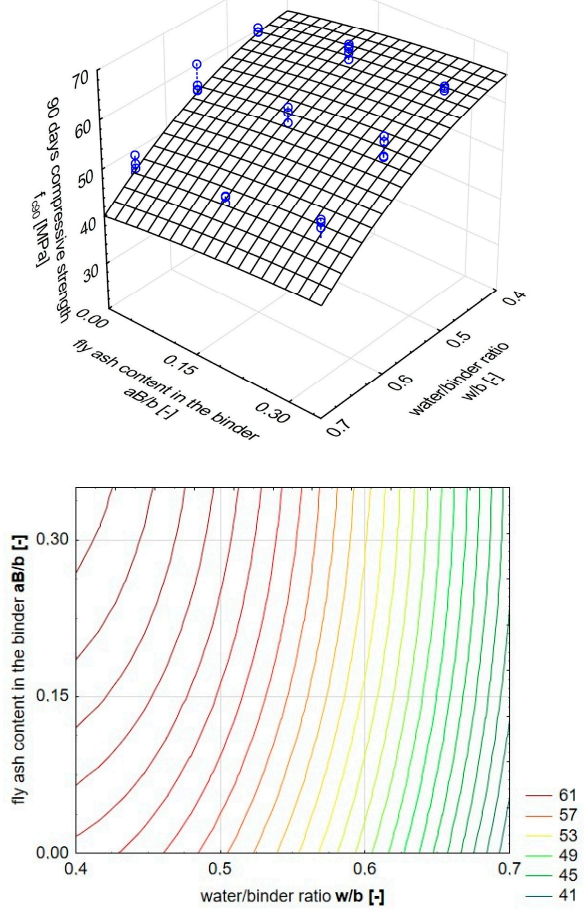

(d)

Figure 2. Compressive strength of concretes with fly ash addition B (lignite) after 28 (a,c) and 90 (b,d) days; test results approximated using a linear function $(\mathbf{a}, \mathbf{b})$ and a second-degree polynomial $(\mathbf{c}, \mathbf{d})$. 
Table 10. Magnitudes of $\mathrm{k}$-factors for fluidized bed combustion fly ashes A and B based on compressive strength test results after 28 days of concrete hardening.

\begin{tabular}{cccc}
\hline \multirow{2}{*}{$w / b$} & Share of Ash, \% by Weight & \multicolumn{2}{c}{ k According to Atis [-] } \\
\cline { 3 - 4 } & & A-Bituminous Coal Fly Ash & B-Lignite Fly Ash \\
\hline \multirow{2}{*}{0.45} & 15 & 1.10 & 1.43 \\
\cline { 2 - 4 } & 30 & 1.05 & 1.25 \\
\hline \multirow{2}{*}{0.55} & 15 & 1.22 & 1.13 \\
\cline { 2 - 4 } & 30 & 1.02 & 1.12 \\
\hline \multirow{2}{*}{0.65} & 15 & 0.91 & 1.60 \\
\cline { 2 - 4 } & 30 & 1.14 & 1.35 \\
\hline & Mean value & 1.07 & 1.31 \\
\hline
\end{tabular}

The average value of the $\mathrm{k}$ factor for fly ash $\mathrm{A}$ is 1.07 . The scatter observed in $\mathrm{k}$ values in Table 10 can be attributed to the manner in which the specimens were stored (in a humidity chamber rather than in water), which may have had some influence on the degree to which the components of the mixed binders reacted with one another. In contrast, the content of FBC FA (B) produced from lignite showed a significant positive effect. As the $\mathrm{aB} / \mathrm{b}$ parameter increased, there was an increase, albeit small, in both strengths. This means that fluidized bed combustion fly ashes as a replacement for part of the cement showed a greater potential in terms of concrete strength than the Portland cement used in the study. Obviously, such an effect only emerges where FBC FA (B) and cement are combined, and it can be assumed that this only occurs within a certain range of proportions. It is clear that with the increase in the proportion of FBC FA (B) in concrete weight of up to $30 \%$ by weight, and thus a corresponding reduction in the amount of cement, compressive strengths of concretes after 28 days and after 90 days are even greater than in concretes in which this fly ash replaced $15 \%$ of cement weight. This further confirms that fly ash B has a greater strength potential when included in binder than cement alone. With reference to the $\mathrm{k}$-factor determined for additives with pozzolanic or hydraulic properties in light of EN 206 [3] (type II), this factor can be expected to be greater than 1.0 (Table 10) for this type of fly ash. A comparison of k-factors for FBC FA (A) and FBC FA (B) shows that the value of this factor for fly ashes produced by lignite combustion is around $20 \%$ higher.

As noted above, the comparison of compressive strength test results for concretes containing FBC FA (A) or (B) fly ashes demonstrates that FBC FA (B), produced by the combustion of lignite, has a greater effect on compressive strength. On the basis of the test results obtained, it is not possible to point to a clear reason for this effect; however, it can be assumed that it is caused by the greater reactivity of this type of fly ash, caused by the higher content of calcium oxide, aluminum oxide and $\mathrm{SO}_{3}$, which, by binding more water in hydration products, reduces the porosity of the hardened binder and thus improves its strength.

\section{Conclusions}

The results of the tests and analyses conducted allow the following conclusions to be drawn and observations to be formulated.

1. Producing concrete mixes using a mixed cement-fly ash binder in which fly ash content is up to $30 \%$ of cement by weight does not pose any special difficulties. However, obtaining mixtures with the desired characteristics requires the careful selection of admixtures which affect their rheological properties, and the proportion of these admixtures must be increased as the proportion of fly ash in the binder increases;

2. The compressive strength relationship for concretes can be described using either a linear equation or a second-degree polynomial. In both cases, around $80 \%$ of the 
variation in compressive strength can be explained by the $w / b$ and $\mathrm{aA} / \mathrm{b}$ or $\mathrm{aB} / \mathrm{b}$ predictors;

3. The dominant factor affecting the compressive strength of the concretes, both after 28 and 90 days of curing, was found to be the water/binder ratio ( $\beta=0.81$ to 0.90$)$;

4. For concretes with fly ash obtained from bituminous coal added, fly ash content in the binder has practically no effect on strength after 28 and 90 days of curing ( $\beta$ close to zero). This can be explained by the very high pozzolanic activity of these materials and their chemical activity, which is the result of their specific mineral and chemical composition;

5. For concretes with fly ash obtained from lignite added, a significant positive effect of its presence in the binder on strength after 28 and 90 days of curing was observed $(\beta=$ from +0.248 to +0.30$)$. This can be attributed to the higher proportion of components that may be responsible for the reactivity of this type of fly ash, e.g., $\mathrm{CaO}$ and $\mathrm{Al}_{2} \mathrm{O}_{3}$;

6. The k-factor values determined for fluidized bed combustion fly ashes used in making concretes are close to 1.0, which is more than twice as high as for traditional fly ashes commonly used in making concretes today. For calcareous fly ash obtained from the combustion of lignite (FBC FA (B)), this parameter is about $20 \%$ higher than for fly ash obtained from the combustion of bituminous coal (FBC FA (A));

7. It should be stressed that the relationships formulated allowing for the prediction of the compressive strength of concretes on the basis of the water/binder ratio and fly ash content in the binder remain valid only for fluidized bed combustion fly ashes with similar chemical composition and grain size distribution and for the type of cement used in the studies presented.

8. The formulated regression equations for predicting the compressive strength after 28 and 90 days of curing represent an important contribution to the knowledge of the qualitative and quantitative influence of the studied fluidized ashes on the properties of concretes. These relationships are almost directly applicable to the practical formulation of concretes made from a blended binder composed of Portland cement and analyzed fluidized ash added in amounts up to $30 \%$ by weight.

Author Contributions: Conceptualization, J.Ś., T.T., A.Ł. and J.D.; methodology, J.Ś. and T.T.; formal analysis, J.D. and A.Ł.; investigation, T.T. and A.Ł.; resources, R.M.; data curation, T.T.; writingoriginal draft preparation, J.Ś., T.T., A.Ł., R.M. and J.D.; writing-review and editing, J.D., R.M. and A.Ł.; visualization, R.M.; supervision, J.D. and J.Ś.; funding acquisition, J.Ś. and J.D. All authors have read and agreed to the published version of the manuscript.

Funding: This work was supported from the subsidy of the Ministry of Science and Higher Education for the Institute of Fundamental Technological Research of Polish Academy of Sciences (project R04 01301 "Application of CFBC flay ash in structural concretes"). The research and analyses concerning the problem presented in the article were carried out as part of a subcontract by teams from the Cracow University of Technology and from the AGH University of Science and Technology in Kraków.

Data Availability Statement: The data presented in this study are available on request from the corresponding author.

Acknowledgments: The authors would like to thank the Ministry of Science and Higher Education, the Cracow University of Technology and AGH University of Science and Technology in Kraków for their financial support.

Conflicts of Interest: The authors declare no conflict of interest. The funders had no role in the design of the study; in the collection, analyses, or interpretation of data; in the writing of the manuscript; or in the decision to publish the results. 


\section{References}

1. Polish Cement Association. Neutralność Klimatyczna A Perspektywy Zastosowania Betonu I Cementu W Budownictwie; II Forum Beton w drogownictwie: Ostróda, Poland, 2020.

2. Brandt, A. (Ed.) Application of CFBC Fly Ash in Structural Concretes; Collective Work; Polish Academy of Science, Committee of Civil Engineering: Warsaw, Poland, 2010.

3. EN 206. Concrete-Specification, Performance, Production and Conformity; European Committee for Stadardization: Bruxelles, Belgium, 2016.

4. Zhang, W.; Choi, H.; Sagawa, T.; Hama, Y. Compressive strength development and durability of an environmental load-reduction material manufactured using circulating fluidized bed ash and blast-furnace slag. Constr. Build. Mater. 2017, 146, 102-113. [CrossRef]

5. Abdulmatin, A.; Tangchirapat, W.; Jaturapitakkul, C. An investigation of bottom ash as a pozzolanic material. Constr. Build. Mater 2018, 186, 155-162. [CrossRef]

6. Gong, B.; Tian, C.; Xiong, Z.; Zhao, Y.; Zhang, J. Mineral changes and trace element releases during extraction of alumina from high aluminum fly ash in inner Mongolia, China. Int. J. Coal Geol. 2016, 166, 96-107. [CrossRef]

7. Hower, J.C.; Groppo, J.G.; Graham, U.M.; Ward, C.R.; Kostova, I.J.; Maroto-Valer, M.M.; Dai, S. Coal-derived unburned carbons in fly ash: A review. Int. J. Coal Geol. 2017, 179, 11-27. [CrossRef]

8. Karayigit, A.I.; Yigitler, O.; Seda, I.; Querol, X.; Mastalerz, M.; Görkem Oskay, R.; Hower, J.C. Mineralogy and Geochemistry of Feed Coals and Combustion Residues from Tunçbilek and Seyitömer Coal-Fired Power Plants in Western Turkey. Coal Combust. Gasif. Prod. 2019, 11, 18-31.

9. Mirkowski, Z.; Jelonek, I. Petrographic Composition of Coals and Products of Coal Combustion from the Selected Combined Heat and Power Plants (CHP) and Heating Plants in Upper Silesia, Poland. Int. J. Coal Geol. 2019, 201, 102-108. [CrossRef]

10. Querol, X.; Fernandez Turiel, J.L.; Lopez Soler, A. The behaviour of mineral matter during combustion of Spanish subbituminous and brown coals. Mineral. Mag. 1994, 58, 119-133. [CrossRef]

11. Sokol, E.V.; Kalugin, V.M.; Nigmatulina, E.N.; Volkova, N.I.; Frenkel, A.E.; Maksimova, N.V. Ferrospheres from fly ashes of chelyabinsk coals: Chemical composition, morphology and formation conditions. Fuel 2002, 81, 867-876. [CrossRef]

12. Valentim, B.; Shreya, N.; Paul, B.; Gomes, C.S.; Sant'Ovaia, H.; Guedes, A.; Ribeiro, J.; Flores, D.; Pinho, S.; Suárez-Ruiz, I.; et al. Characteristics of ferrospheres in fly ashes derived from Bokaro and Jharia (Jharkand, India) coals. Int. J. Coal Geol. 2016, 153, 52-74. [CrossRef]

13. Małolepszy, M.; Gawlicki, M.; Mróz, R. Properties of Two-and Three-Component Blended Cements with Different Types of Fly Ashes. In Proceedings of the 9th CANMET / ACI International Conference on Fly Ash, Silica Fume, Slag, and Natural Pozzolans in Concrete, Warsaw, Poland, 1 April 2007.

14. Łagosz, A.; Mróz, R. Durability of building materials based on mineral binders modified by significant amounts of fly ash from brown coal combustion in fluidized bed. React. Solids 2013, 115, 259-267.

15. Zhou, M.; Chen, P.; Chen XGe, X.; Wang, Y. Study on hydration characteristics of circulating fluidized bed combustion fly ash (CFBCA). Constr. Build. Mater. 2020, 251, 118993. [CrossRef]

16. Sheng, G.; Li, Q.; Zhai, J. Investigation on the hydration of CFBC fly ash. Fuel 2012, 98, 61-66. [CrossRef]

17. Li, X.; Chen, Q.; Huang, K.; Ma, B.; Wu, B. Cementitious properties and hydration mechanism of circulating fluidized bed combustion (CFBC) desulfurization ashes. Constr. Build. Mater. 2012, 36, 182-187. [CrossRef]

18. Suárez-Ruiz, I.; Valentim, B.; Borrego, A.G.; Bouzinos, A.; Flores, D.; Kalaitzidis, S.; Malinconico, M.L.; Marques, M.; MiszKennan, M.; Predeanu, G.; et al. Development of a petrographic classification of fly-ash components from coal combustion and co-combustion. (An ICCP Classification System, Fly-Ash Working Group-Commission III.). Int. J. Coal Geol. 2017, 183, 188-203. [CrossRef]

19. Styszko-Grochowiak, K.; Golłaś, J.; Jankowski, H.; Koziński, S. Characterization of the coal fly ash for the purpose of improvement of industrial on-line measurement of unburned carbon content. Fuel 2004, 83, 1847-1853. [CrossRef]

20. Li, D.; Sun, R.; Wang, D.; Ren, C.; Fang, K. Study on the pozzolanic activity of ultrafine circulating fluidized-bed fly ash prepared by jet mill. Fuel 2021, 291, 120220. [CrossRef]

21. Gazdiča, D.; Fridrichová, M.; Kulíseka, K.; Vehovská, L. The potential use of the FBC ash for the preparation of blended cements. Procedia Eng. 2017, 180, 1298-1305. [CrossRef]

22. Lee, B.Y.; Jeon, S.; Cho, C.G.; Kim, H. Evaluation of time to shrinkage-induced crack initiation in OPC and slag cement matrices incorporating circulating fluidized bed combustion bottom ash. Constr. Build. Mater. 2020, 257, 119507. [CrossRef]

23. Gawlicki, M.; Roszczynialski, W. Applicabillity of combustion by-products from fluidized bed as Portland cement components. Ceramics 2003, 80, 681-686.

24. Osholanaa, T.S.; Dludlub, M.K.; Oboirienc, B.; Sadikua, R. Enhanced reactivity of geopolymers produced from fluidized bed combustion bottom ash. S. Afr. J. Chem. Eng. 2020, 34, 72-77. [CrossRef]

25. Leong, H.Y.; Ong, D.E.L.; Sanjayan, J.G.; Nazari, A. Strength development of soil-fly ash geopolymer: Assessment of soil, fly ash, alkali activators, and water. J. Mater. Civ. Eng. 2018, 30. [CrossRef]

26. Leong, H.Y.; Ong, D.E.L.; Sanjayan, J.G.; Nazari, A.; Kueh, S.M. Effects of significant variables on compressive strength of soil-fly ash geopolymer: Variable analytical approach based on neural networks and genetic programming. J. Mater. Civ. Eng. 2018, 30. [CrossRef] 
27. Liu, Z.; Li, S.; Li, S.; Wang, J.; Zhou, Y.; Wang, D. One-step high efficiency crystallization of zeolite A from ultra-fine circulating fluidized bed fly ash by hydrothermal synthesis method. Fuel 2019, 257, 116043. [CrossRef]

28. Xu, X.; Hu, Z.; Duan, L.; Zhang, Y.; Xiao, Y.; Lin, W. Investigation of high volume of CFBC ash on performance of basic magnesium sulfate cement. J. Environ. Manage. 2020, 256, 109878. [CrossRef] [PubMed]

29. Song, Y.; Guo, C.; Qian, J.; Ding, T. Effect of the Ca-to-Si ratio on the properties of autoclaved aerated concrete containing coal fly ash from circulating fluidized bed combustion boiler. Constr. Build. Mater. 2015, 83, 136-142. [CrossRef]

30. Drochytkaa, R.; Helanováa, E. Development of microstructure of the fly ash aerated concrete in time. Procedia Eng. 2015, 108, 624-631. [CrossRef]

31. Xia, Y.; Yan, Y.; Hu, Z. Utilization of circulating fluidized bed fly ash in preparing non-autoclaved aerated concrete production. Constr. Build. Mater 2013, 47, 1461-1467. [CrossRef]

32. Zahedi, M.; Jafari, K.; Rajabipour, F. Properties and durability of concrete containing fluidized bed combustion (FBC) fly ash. Constr. Build. Mater 2020, 258, 119663. [CrossRef]

33. Janowska-Renkas, E.; Kaliciak, A. Impact of fly ashes from combustion in fluidized bed boilers and siliceous fly ashes on durability of mortars exposed to seawater and carbonation process. Materials 2021, 14, 2345. [CrossRef]

34. Chi, M.; Huang, R. Effect of circulating fluidized bed combustion ash on the properties of roller compacted concrete. Cem. Concr. Compos. 2014, 45, 148-156. [CrossRef]

35. Horszczaruk, E.; Brzozowski, P. Effects of fluidal fly ash on abrasion resistance of underwater repair concrete. Wear 2017, 376, 15-21. [CrossRef]

36. Horszczaruk, E.; Brzozowski, P. Properties of underwater concretes containing large amount of fly ashes. Procedia Eng. 2017, 196, 97-104. [CrossRef]

37. EN 197-1. Cement-Part 1: Composition, Specifications and Conformity Criteria for Common Cements; European Committee for Stadardization: Bruxelles, Belgium, 2012.

38. EN 450-1. Fly Ash for Concrete-Part 1: Definition, Specifications and Conformity Criteria; European Committee for Stadardization: Bruxelles, Belgium, 2012.

39. EN 12350-2. Testing Fresh Concrete-Part 2: Slump test; European Committee for Stadardization: Bruxelles, Belgium, 2019.

40. EN 12350-7. Testing Fresh Concrete-Part 7: Air Content_Pressure Methods; European Committee for Stadardization: Bruxelles, Belgium, 2019.

41. EN 12390-3. Testing Hardened Concrete_Part 3: Compressive Strength of Test Specimens; European Committee for Stadardization: Bruxelles, Belgium, 2019.

42. EN 196-2. Method of Testing Cement-Part 2: Chemical Analysis of Cement; European Committee for Stadardization: Bruxelles, Belgium, 2013.

43. EN 451-1. Method of Testing fly Ash-Part 1: Determination of Free Calcium Oxide Content; European Committee for Stadardization: Bruxelles, Belgium, 2017.

44. EN 196-3. Methods of Testing Cement-Part 3: Determination of Setting Times and Soundness; European Committee for Stadardization: Bruxelles, Belgium, 2016.

45. EN 12620. Aggregates for Concrete; European Committee for Stadardization: Bruxelles, Belgium, 2010.

46. EN 12390-2. Testing Hardened Concrete-Part 2: Making and Curing Specimens for Strength Tests; European Committee for Stadardization: Bruxelles, Belgium, 2019.

47. Atis, C.D. Strength properties of high-volume fly ash roller compacted and workable concrete, and influence of curing condition. Cem. Concr. Res. 2005, 35, 1112-1121. [CrossRef] 